\title{
Bacillus silvestris sp. nov., a new member of the genus Bacillus that contains lysine in its cell wall
}

\author{
Holger Rheims, ${ }^{1}$ Anja Frühling, ${ }^{1}$ Peter Schumann, ${ }^{1}$ Manfred Rohde ${ }^{2}$ \\ and Erko Stackebrandt ${ }^{1}$
}

DSMZ - Deutsche

Sammlung von

Mikroorganismen und

Zellkulturen $\mathrm{GmbH}^{1}$ and

GBF - Gesellschaft für

Biotechnologische

Forschung $\mathrm{mbH}$, Bereich

Mikrobiologie'2, D-38124

Braunschweig, Germany
Author for correspondence: Erko Stackebrandt. Tel: +49531 2616352. Fax: +495312616418. e-mail: erko@dsmz.de

\begin{abstract}
A Gram-positive, aerobic, rod-shaped, peritrichously flagellated, roundendospore-forming bacterium was isolated from a forest soil near Braunschweig, Lower Saxony, Germany, and designated strain HR3-23' (T = type strain). Morphologically, strain HR3-23' shows the characteristics of a member of the genus Bacillus. The spore position is terminal in a swollen sporangium. Comparative analysis of the 165 rDNA sequence shows strain HR3-23' to be most closely related to Caryophanon tenue (95.8\% 165 rRNA similarity) and to Bacillus sphaericus (95.4\% 16 S rRNA similarity). Phylogenetically, the isolate clusters among species of Bacillus RNA group 2. The DNA G+C content of isolate $\mathrm{HRB}^{-23^{\mathrm{T}}}$ is $39 \cdot 3 \mathrm{~mol} \%$, the peptidoglycan type is A4 $\alpha$ (L-Lys-D-Glu), the major respiratory lipoquinone is menaquinone MK-7 and the predominant fatty acid is of the iso- $\mathrm{C}_{15: 0}$ type. Based on the morphological, chemotaxonomic, physiological and phylogenetic properties, a new species, Bacillus silvestris, is proposed; strain HR3-23 is the type strain (= DSM 12223').
\end{abstract}

Keywords: Bacillus silvestris, Bacillus RNA group 2, 16S rDNA analysis, phylogeny, chemotaxonomy

\section{INTRODUCTION}

The genus Bacillus, as defined traditionally, comprises Gram-positive, rod-shaped, endospore-forming bacteria with an aerobic or facultatively aerobic metabolism. The recognition that this genus is 'a diverse assemblage that is a grouping of convenience' (Sneath, 1986) was furthermore demonstrated a few years later by comprehensive analyses of $16 \mathrm{~S}$ rDNA nucleotide sequences of members of this genus (Ash et al., 1991; Farrow et al., 1992, 1994; Rainey \& Stackebrandt, 1993; Rainey et al., 1994). These findings provided the basis for the dissection of the genus Bacillus to describe several new genera containing former Bacillus species, such as Alicyclobacillus (Wisotzkey et al., 1992), Aneurinibacillus (Shida et al., 1996), Brevibacillus

Abbreviations: SEM, scanning electron microscopy; TEM, transmission electron microscopy; VP test, Voges-Proskauer test.

The EMBL accession number for the 165 rDNA sequence of Bacillus silvestris HR3-23 $3^{\mathrm{T}}$ is AJ006086.
(Shida et al., 1996), Paenibacillus (Ash et al., 1993) and Virgibacillus (Heyndrickx et al., 1998). Analysis of 16S rDNA has developed into a fast and reliable method for phylogenetic affiliation of a novel isolate to one of these genera.

The rRNA group 2 of the genus Bacillus (Ash et al., 1991), comprises round-spore-forming members of the genus Bacillus, containing L-lysine or D-ornithine at position three of the peptide subunit (Stackebrandt et al., 1987). Analysis of 16S rRNA of Gram-positive bacteria from other genera indicated that this Bacillus group also contains non-Bacillus-type organisms, such as members of Caryophanon and Planococcus (Stackebrandt et al., 1987; Farrow et al., 1994), Filibacter (Clausen et al., 1985) and Sporosarcina (Pechman et al., 1976; Farrow et al., 1992).

In this work, we describe a new round-spore-forming species of the genus Bacillus that was isolated from forest soil. Phylogenetically and chemotaxonomically, it is related to members of Bacillus RNA group 2. The isolate can be distinguished from other species of this 
group by the primary structure of the $16 \mathrm{~S}$ rDNA and its phenotypic properties.

\section{METHODS}

Isolation of and cultural conditions for strain HR3-23'. A soil sample was taken from a beech forest soil near Braunschweig, Germany. The sample $(10 \mathrm{~g})$ was placed into a Petri dish which was then stored in a jar with moistened paper cloths. Following incubation at $40^{\circ} \mathrm{C}$ for $15 \mathrm{~min}$, the soil was subsequently suspended in $100 \mathrm{ml}$ germination solution. The germination solution consisted of $10^{-1}$ concentrated glucose/yeast extract/malt extract medium $(0.4 \mathrm{~g}$ glucose, $0.4 \mathrm{~g}$ yeast extract, $1.0 \mathrm{~g}$ malt extract, $0.2 \mathrm{~g} \mathrm{CaCO}_{3}$ in 11 distilled water) with the addition of $1.0 \mathrm{~g} \mathrm{~L}$-asparagine. After autoclaving, the solution was allowed to cool down to room temperature. A filter-sterilized cycloheximide solution $(0.1 \mathrm{~g}$ dissolved in $10 \mathrm{ml}$ water $)$ was added.

Two subsequent tenfold dilutions of the soil suspension in germination solution were set up. The $10^{-3}$ dilution step was stirred at room temperature for $15 \mathrm{~min}$. Aliquots of $100 \mu \mathrm{l}$ were then streak-plated on different isolation media and incubated at different temperatures.

Strain HR3-23 $3^{\mathrm{T}}$ was isolated from a plate with Difco tryptic soy broth agar (Difco; amended with 3.0 g yeast extract $1^{-1}$

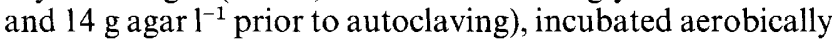
for $1 \mathrm{~d}$ at $25^{\circ} \mathrm{C}$. Purity of the culture was confirmed by serial plating onto the same medium. Good growth of the isolate was also observed on the R-medium of Yamada \& Komagata (1972).

Determination of physiological characteristics. The following physiological tests were carried out according to Gordon et al. (1973): catalase and oxidase reactions, anaerobic growth, Voges-Proskauer (VP) test, temperature range for growth $\left(5-55^{\circ} \mathrm{C}\right.$ in steps of $\left.5^{\circ} \mathrm{C}\right)$, presence of lecithinase, resistance to lysozyme, growth in the presence of $\mathrm{NaCl}(0,2,5,7$ and $10 \%$ ), growth at $\mathrm{pH} 5 \cdot 7$, formation of acid from D-glucose, L-arabinose, D-xylose, D-mannitol, D-fructose, formation of gas from glucose, hydrolysis of starch, decomposition of Tween 80 , use of citrate and propionate, reduction of nitrate, production of indole, deamination of phenylalanine, decomposition of casein and tyrosine, liquefaction of gelatin and presence of arginine dihydrolase.

Hydrolysis of aesculin was tested according to Lanyi (1989) in a medium consisting of $10.0 \mathrm{~g}$ Bacto-peptone, $1.0 \mathrm{~g}$ sodium citrate, $1.0 \mathrm{~g}$ aesculin and $0.05 \mathrm{~g}$ iron citrate in 11 water at $\mathrm{pH} 6 \cdot 8-7 \cdot 0$.

A loopful of cell material of strain HR3-23 ${ }^{\mathrm{T}}$ was used to set up an overnight culture on a plate of Difco tryptic soy broth agar, incubated at $25^{\circ} \mathrm{C}$. From this culture, a suspension corresponding to McFarland standard 1 (OD $_{550}$ of $0 \cdot 25$; bioMérieux) was prepared in $1 \mathrm{ml}$ sterile water. One drop of this suspension was added to each of the test tubes.

Growth in the VP test, $\mathrm{NaCl}$ tolerance and the presence of lecithinase were negative under the conditions described by Gordon et al. (1973), even after prolonged incubation. Therefore, these tests were repeated, adding half a volume of a $0.1 \%(\mathrm{w} / \mathrm{v})$ sterile yeast extract solution to the culture suspension prior to inoculation. As growth failed or was too poor for a sound evaluation, these tests were repeated using the following media. For the VP test, a medium consisting of $5.0 \mathrm{~g}$ glucose, $5.0 \mathrm{~g}$ peptone from tryptic-digested casein, and $5.0 \mathrm{~g} \mathrm{KH}_{2} \mathrm{PO}_{4}$ in 11 water, $\mathrm{pH} 7.2$ was used. For the test of growth in the presence of different $\mathrm{NaCl}$ concentrations, culture tubes of Difco tryptic soy broth (prepared with the addition of yeast extract as described above) were set up containing various amounts of $\mathrm{NaCl}$.

The lecithinase test was repeated with Difco tryptic soy broth agar medium to which $5 \mathrm{ml}$ egg yolk (egg yolk emulsion; Oxoid) was added after the medium had cooled down following autoclaving.

Physiological reactions were also tested using the substrate panel of the API 50CH system (bioMérieux).

\section{Microscopic investigations}

Primary morphological characterization was done by light microscopy, including phase-contrast observations. The size and ultrastructure of cells and spores were determined by electron microscopy.

Light microscopy. For the investigation of cell morphology, $2 \%(\mathrm{w} / \mathrm{v})$ agar (dissolved in water)-covered slides were prepared. A drop of culture grown in TSB medium (trypticase soy broth; Becton Dickinson) overnight was placed on the agar. Flagella were stained according to the method of Heimbrook et al. (1989).

Transmission electron microscopy (TEM). Cells were centrifuged, washed with $\mathrm{PBS}(0 \cdot 145 \mathrm{M} \mathrm{NaCl}, 0 \cdot 15 \mathrm{M}$ sodium phosphate; Sambrook et al., 1989) and fixed on ice for $1 \mathrm{~h}$ with a fixation solution containing $3 \%(\mathrm{v} / \mathrm{v})$ glutaraldehyde and $5 \%(\mathrm{v} / \mathrm{v})$ formaldehyde. After three washings with PBS, samples were embedded in $1.5 \%(\mathrm{w} / \mathrm{v})$ agar in water; the solidified agar was cut into small cubes and dehydrated on ice with a graded series of acetone (10, 30, 50 and $70 \%$ for $30 \mathrm{~min}$ each). At the $70 \%$ acetone dehydration step, the samples were treated with $2 \%(\mathrm{w} / \mathrm{v})$ uranyl acetate in $70 \%$ acetone (overnight). Samples were then further dehydrated with 90 and $100 \%$ acetone (30 min on ice) and once in $100 \%$ acetone at room temperature for $1 \mathrm{~h}$.

For infiltration with epoxy resin (using Spurr's resin formula; Spurr, 1969), samples were initially treated according to the following protocol: one part $100 \%$ acetone with one part resin for $6 \mathrm{~h}$; one part acetone and two parts resin overnight; pure resin for another $2 \mathrm{~d}$ with several changes. Samples were then transferred to gelatin capsules which were filled with pure resin. Polymerization was at $70^{\circ} \mathrm{C}$ for $8 \mathrm{~h}$. After trimming of the samples, ultrathin sections cut with glass knives were collected onto Formvar-coated copper grids ( 300 mesh) and air-dried. Counter-staining was done with a Leica Ultrostainer (uranyl acetate at $40^{\circ} \mathrm{C}$ for $30 \mathrm{~min}$, lead citrate at $20^{\circ} \mathrm{C}$ for $3 \mathrm{~min}$ ). Samples were examined in a Zeiss EM910 TEM at an acceleration voltage of $80 \mathrm{kV}$ and at calibrated magnifications.

Scanning electron microscopy (SEM). A culture was grown on the isolation agar medium for $24 \mathrm{~h}$. Agar blocks were cut from the plate, fixed in $2.5 \%(\mathrm{v} / \mathrm{v})$ glutaraldehyde and dehydrated on ice in a series of increasing acetone concentrations $(10,30$, $50,70,90$ and $100 \%$ for $10 \mathrm{~min}$ each). Preparations were dried at the critical point of liquid $\mathrm{CO}_{2}$, sputter-coated with gold (10 nm thickness) and examined in a Zeiss model DSM 982 SEM.

Analysis of chemotaxonomic characteristics. Cell wall and lipid analysis were carried out as described previously (Groth et al., 1996) using the methods of Schleifer \& Kandler (1972), MacKenzie (1987), Stead et al. (1992), Collins et al. (1977), Minnikin et al. (1979, 1975) and Collins \& Jones (1980). 

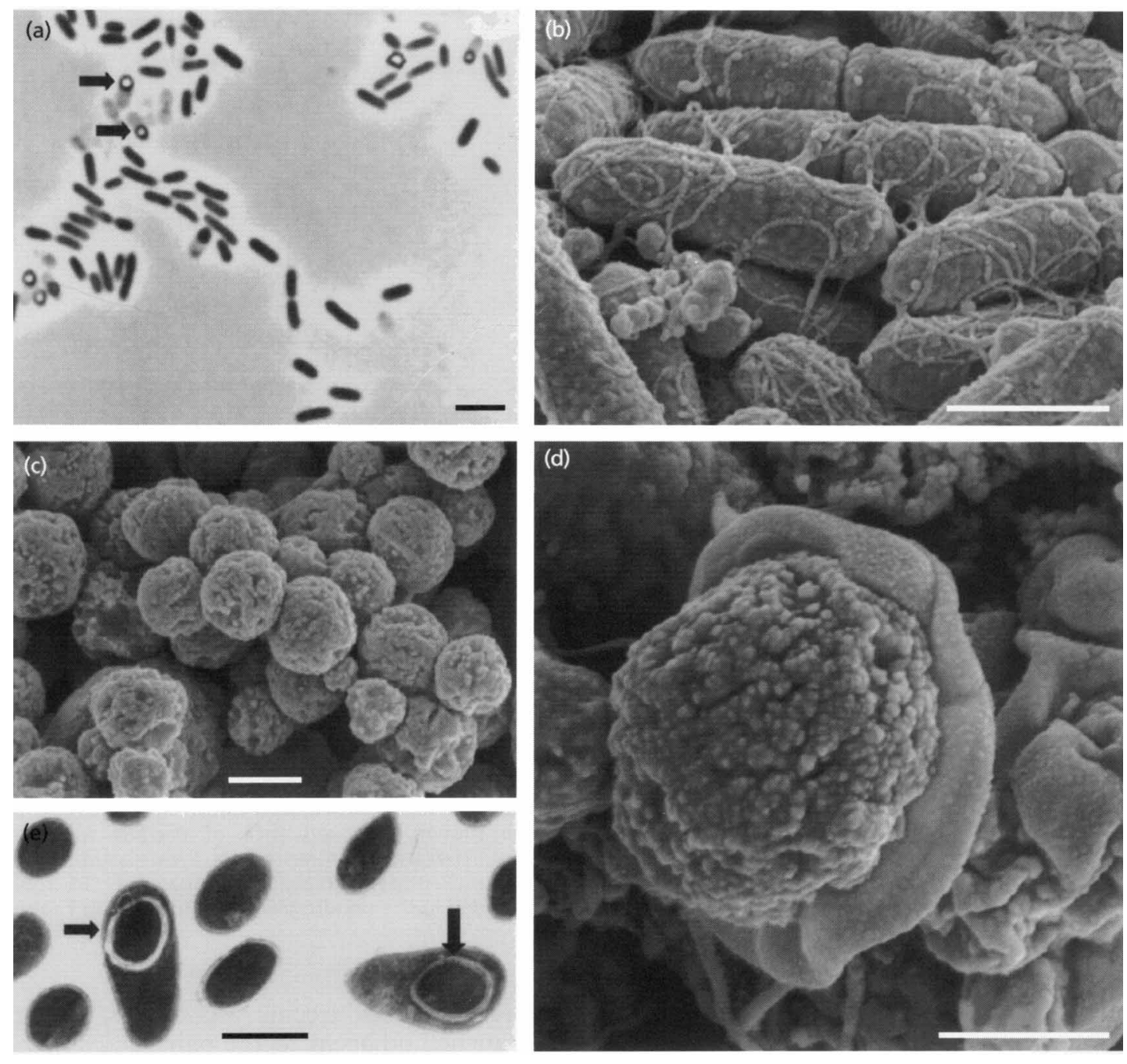

Fig. 1. Microscopic images of cells of strain HR3-23 $3^{T}$ grown on TSB medium; arrows mark the spore positions. (a) Light microscopic image; bar, $2 \mu \mathrm{m}$. (b) SEM image of flagellated vegetative cells; bar, $1 \mu \mathrm{m}$. (c) SEM image of spores; the vegetative cell walls have already been fully lysed; bar, $0.5 \mu \mathrm{m}$. (d) Detail of an SEM image of a spore; remains of the cell wall of the vegetative cell are visible; bar, $0.25 \mu \mathrm{m}$. (e) TEM image of cut cells containing spores; the typical bi-layered structure of the endospore cell wall can be seen; bar, $1 \mu \mathrm{m}$.

\begin{abstract}
Isolation of DNA for determination of the $\mathrm{G}+\mathrm{C}$ value ( $\mathrm{mol} \%$ ) and for PCR-amplification of the 16S rRNA gene. Genomic DNA was extracted by an enzymic lysis procedure as described by Rainey et al. (1996). G+C contents were determined by HPLC (Mesbah et al., 1989). An aliquot of the isolated DNA was also used for PCR-mediated amplification of the 16S rDNA (Rainey et al., 1996). The PCR products were purified by using a QIAquick PCR purification kit (Qiagen) and directly sequenced using previously described protocols (Rainey et al., 1996). The sequence reaction mixtures were electrophoresed using a model 373A automatic DNA sequencer (Applied Biosystems).
\end{abstract}

Phylogenetic analysis. The 16S rDNA sequence of isolate HR3-23 $3^{\mathrm{T}}$ was initially aligned to the sequences of a general selection of different bacteria of the DSMZ identification database and, after a first phylogenetic analysis, with members of and relatives to the RNA group 2 of the genus Bacillus [as defined by Ash et al. (1991) and Farrow et al. (1994)] using the ae2 editor (Maidak et al., 1997). Evol- utionary distances were calculated by the method of Jukes \& Cantor (1969). Phylogenetic dendrograms according to the method of De Soete (1983) and also dendrograms obtained by the use of the neighbour-joining method contained in the PHYLIP package (Felsenstein, 1993) were constructed. Bootstrap analysis (Felsenstein, 1985) was used to evaluate the tree topology of the neighbour-joining data by performing 500 resamplings.

\section{RESULTS}

\section{Morphology}

Strain HR3-23 ${ }^{\mathrm{T}}$ developed whitish shiny colonies on agar media. It formed peritrichously flagellated rods with a length of $0.9-2.0 \mu \mathrm{m}$ and a width of $0.5-0.7 \mu \mathrm{m}$ (Fig. 1a, b). Round terminal spores having a diameter of $0.5-0.7 \mu \mathrm{m}$ were observed in swollen sporangia after growth in TSB. The ultrastructural investigation of the 
spore surface showed a cauliflower-like fine structure (Fig. 1c). Remaining parts of the lysed vegetative cell wall were still found to be attached to a few of the investigated spores (Fig. 1d). In the images obtained from the ultrathin sections of cells, the typical bilayered bacterial endospore cell wall structure was observed (Fig. 1e).

\section{Physiological characteristics}

Growth of isolate HR3-23 $3^{\mathrm{T}}$ occurred at $10-40{ }^{\circ} \mathrm{C}$ with an optimum of $20-30^{\circ} \mathrm{C}$. The following results were obtained after cultivation at $28^{\circ} \mathrm{C}$. The organism did not grow at pH 5.7. Growth was observed on modified Difco tryptic soy broth agar (see Methods) in the presence of 0,2 and $5 \%(\mathrm{w} / \mathrm{v}) \mathrm{NaCl}$; no growth was observed at these $\mathrm{NaCl}$ concentrations in medium according to Gordon et al. (1973). The isolate was positive for catalase and negative for oxidase. Anaerobic growth did not occur. No acid was produced from D-glucose, L-arabinose, D-xylose, D-mannitol and D-fructose. From the 49 substrates provided in the API $50 \mathrm{CH}$ strip, acid was produced only from sucrose after $3 \mathrm{~d}$ incubation.

Production of gas from glucose was not observed and the $\mathrm{pH}$ of carbohydrate-containing media was not changed. From the tests of the API 50CH auxiliary panel, only utilization of glycerol (after $48 \mathrm{~h}$ ) and ribose (after $5 \mathrm{~d}$ ) was indicated by an increased turbidity.

The VP test and egg yolk lecithinase test were negative, indole was not formed. No hydrolysis of casein, gelatin, starch, Tween 80 or aesculin was observed. Strain HR3 $-23^{\mathrm{T}}$ did not utilize citrate or propionate and did not degrade tyrosine. Deamination of phenylalanine was negative and nitrate was not reduced to nitrite. No growth occurred in the presence of lysozyme. Arginine dihydrolase activity was not detected.

\section{Phylogenetic analysis and DNA base composition}

A $1449 \mathrm{nt}$ stretch of the 16S rRNA gene of isolate HR3 $-23^{\mathrm{T}}$ was sequenced, representing $94.0 \%$ of the Escherichia coli gene sequence (Brosius et al., 1978). Similarity values calculated for the sequence of strain HR $3-23^{\mathrm{T}}$ and other bacterial sequences indicated a membership to the genus Bacillus. The similarity values were above $91 \%$ for members of the Bacillus RNA group 2 [as defined by Ash et al. (1991) and Farrow et al. (1992)]. The highest values were found with members of the genus Caryophanon, i.e. Caryophanon tenue NCDO $2324^{\mathrm{T}}(95.8 \%)$ and Caryophanon latum NCIMB $9533^{\mathrm{T}}(95.6 \%)$ and with Bacillus sphaericus NCDO 1767 (95.4\%). The similarity of strain HR3-23 ${ }^{\mathrm{T}}$ to the $16 \mathrm{~S}$ rDNA sequence of the type strain of the species B. sphaericus, ATCC $14577^{\mathrm{T}}$, was determined to be $94.2 \%$. The sequences of NCDO 1767 and ATCC $14577^{\mathrm{T}}$ showed a similarity value of $98.5 \%$ to each other.

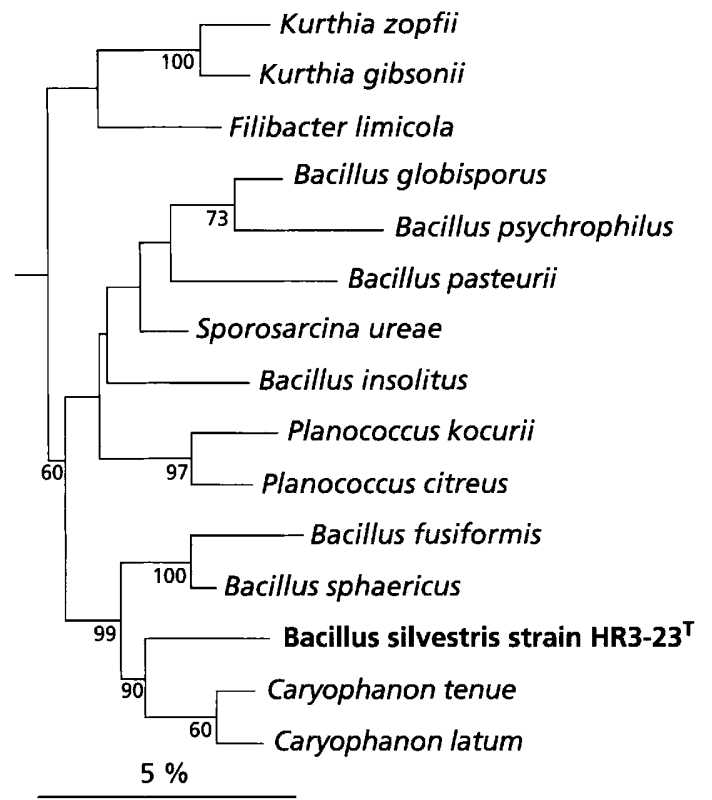

Fig. 2. Phylogenetic tree of strain $H R 3-23^{\top}$ and related organisms from Bacillus RNA group 2. The dendrogram was obtained by the neighbour-joining method contained in the PHYLIP package (Felsenstein, 1993). Numbers at branching points indicate percentages of occurrence of the branching order in 500 bootstrapped trees (only values of 60 and above are shown). The sequence of Bacillus subtilis served as a root. The scale bar represents 5 nucleotide substitutions per 100 nucleotides. Accession numbers of 165 rDNA sequences included in the dendrogram are indicated in Table 1.

Irrespective of treeing algorithms, isolate HR3-23 branched adjacent to the pair B. sphaericus, Bacillus fusiformis and members of the genus Caryophanon. This branching order is also supported by high bootstrap values (Fig. 2; see also Table 1). The only variation was found in the branching order of members of the genera Planococcus and Kurthia. When the algorithm of De Soete (1983) was used, their position changed to form a lineage adjacent to $B$. sphaericus and related species (data not shown).

\section{Chemotaxonomic properties}

The fatty acid profile of isolate HR $3-23^{\mathrm{T}}$ was characterized by the predominance of iso- $\mathrm{C}_{15: 0}(44.2 \%)$, followed by iso- $\mathrm{C}_{16: 1}(18.7 \%)$ fatty acids. Smaller amounts were found for iso- $\mathrm{C}_{14: 0}(2.9 \%)$, anteiso$\mathrm{C}_{15: 0}(5 \cdot 6 \%)$, iso- $\mathrm{C}_{16: 0}(6 \cdot 2 \%), \mathrm{C}_{16: 1}(3 \cdot 1 \%)$, iso- $\mathrm{C}_{17: 0}$ $(5.1 \%)$, anteiso- $\mathrm{C}_{17: 0}(3.0 \%)$, iso- $\mathrm{C}_{17: 1}(7.8 \%)$, anteiso- $\mathrm{C}_{17: 1}(2.8 \%)$ and $\mathrm{C}_{17: 0}(0.9 \%)$. The peptidoglycan of isolate HR3-23 $23^{\mathrm{T}}$ contained lysine, glutamic acid and alanine, representing peptidoglycan type $A 4 \alpha$ (L-Lys-D-Glu) as described by Schleifer \& Kandler (1972). Isoprenoid quinones were MK-7, MK-6 and MK-8 at a peak area ratio of $84: 4: 1$. Polar lipids comprised phosphatidylglycerol, diphosphatidylglycerol, phosphatidylethanolamine, minor amounts of phosphatidylserine and one unknown phospholipid. 
Table 1. Chemotaxonomic properties of strain $\mathrm{HR}-23^{\top}$ and related organisms from Bacillus RNA group 2

Strains: 1, Kurthia zopfii NCIMB 9878 $; 2$, Kurthia gibsonii NCIMB 9758 $; 3$, Filibacter limicola NCIMB $11925^{\mathrm{T}} ; 4$, Bacillus globisporus NCIMB $11434^{\mathrm{T}} ; 5$, Bacillus psychrophilus ATCC $23304^{\mathrm{T}} ; 6$, Bacillus pasteurii NCIMB $8841^{\mathrm{T}} ; 7$, Sporosarcina ureae NCIMB 9251 $; 8$, Bacillus insolitus DSM 5 $; 9$, Planococcus kocurii NCIMB 629 $; 10$, Planococcus citreus NCIMB 1493 ${ }^{\mathrm{T}}$; 11 , Bacillus fusiformis DSM 2898 ${ }^{\mathrm{T}} ; 12$, Bacillus sphaericus NCDO 1767; 13, Bacillus silvestris HR3-23 ${ }^{\mathrm{T}}\left(=\mathrm{DSM}_{\left.1223^{\mathrm{T}}\right)}\right.$; 14, Caryophanon tenue NCDO $2324^{\mathrm{T}} ; 15$, Caryophanon latum NCIMB $9533^{\mathrm{T}}$.

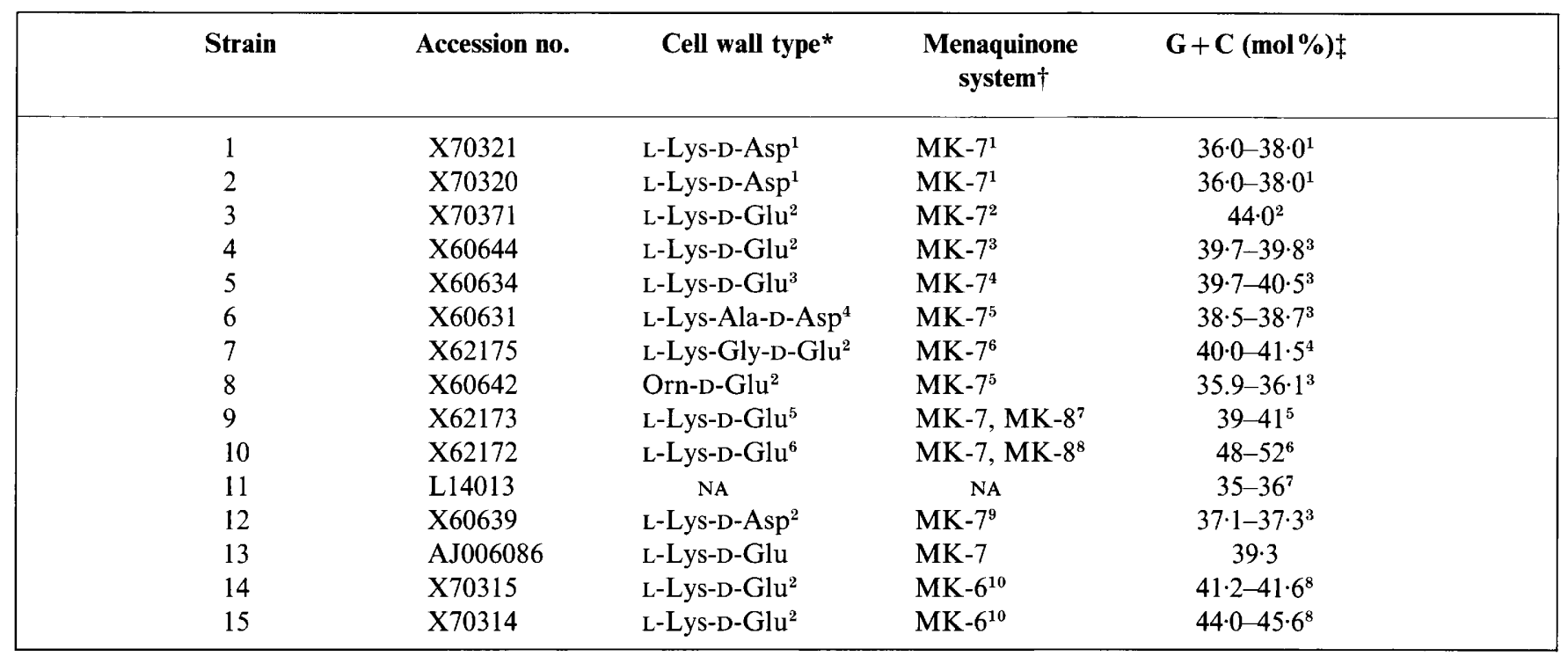

NA, Data not available.

* Data from: 1, Shaw \& Keddie (1983); 2, Stackebrandt et al. (1987); 3, Claus \& Fritze (1989); 4, Ranftl \& Kandler (1970); 5, Hao et al. (1985); 6, Kocur (1986).

† Data from: 1, Shaw \& Keddie (1983); 2, Maiden \& Jones (1984); 3, Fahmy et al. (1985); 4, D. Fritze, personal communication; 5, Hess et al. (1979); 6, Claus \& Fahmy (1986); 7, Hao et al. (1985); 8, Kocur (1986); 9, Collins \& Jones (1979); 10, Holt et al. (1994). ¥Data from: 1, Shaw \& Keddie (1983); 2, Maiden \& Jones (1984); 3, Fahmy et al. (1985); 4, Claus \& Fahmy (1986); 5, Hao et al. (1985); 6, Kocur (1986); 7, Priest et al. (1988); 8, Trentini (1986).

The $\mathrm{G}+\mathrm{C}$ content of the DNA of isolate HR3-23 $23^{\mathrm{T}}$ was $39 \cdot 3 \mathrm{~mol} \%$.

\section{DISCUSSION}

Morphological and phylogenetic analyses have clearly demonstrated that strain HR3-23 $3^{\mathrm{T}}$ is a member of the genus Bacillus. Based upon the results of physiological properties, strain HR3-23 $23^{\mathrm{T}}$ appears to be most similar to Bacillus fastidiosus, but this phenotypic relationship is due to the significant number of negative test results obtained for the isolate and B. fastidiosus (Claus \& Berkeley, 1986). In addition, while B. fastidiosus requires a medium containing allantoin or uric acid (Claus \& Berkeley, 1986), contains peptidoglycan with meso-diaminopimelic acid as the diagnostic amino acid and is phylogenetically a member of the Bacillus RNA group 1, strain HR3-23 $3^{\mathrm{T}}$ contains peptidoglycan with lysine as the diagnostic amino acid and clusters with the Bacillus RNA group 2 and its non-Bacillustype relatives.

The phylogenetic relationship among the round-sporeforming bacilli and their non-spore-forming relatives has been extensively investigated and discussed by
Farrow et al. (1994). Their findings regarding the branching order within the RNA group 2 bacilli were confirmed by the present study. The sequence of Filibacter limicola was not included in the study of Farrow et al. (1994), but membership of this species in Bacillus RNA group 2 had previously been demonstrated by oligonucleotide cataloguing (Stackebrandt et al., 1987). In contrast to the few branching points which are supported by a high bootstrap value, most of the branching points of the more deeply branching lineages are not statistically significant, hence the order at which these lineages evolved remains uncertain. One of the few clusters supported by high bootstrap values embraces the genus Caryophanon and some Bacillus species, including the novel isolate HR3-23 ${ }^{\mathrm{T}}$. From a phylogenetic point of view, the latter strain and Caryophanon species share a common ancestry which strengthens the evolutionary origin of the morphologically different Caryophanon species from Bacillus-type ancestors.

Although the taxonomic status of the RNA group 2 bacilli has been discussed (Farrow et al., 1994), no formal proposal has as yet been forwarded which transfers the L-lysine- and ornithine-containing bacilli 
into one or, because of the phylogenetic intermixing with non-Bacillus-type genera, several new genera. Hence, any strain worthy of species rank within RNA group 2, exhibiting taxonomic properties that would identify this taxon as a member of the genus Bacillus, should still be described as a species of this genus. Based upon phylogenetic, chemotaxonomic and morphological properties, strain $\mathrm{HR} 3-23^{\mathrm{T}}$ represents a member of this genus; based upon phylogenetic distance and physiological properties, strain HR $3-23^{\mathrm{T}}$ represents a new species. No DNA-DNA hybridization studies were carried out, as the binary $16 \mathrm{~S}$ rDNA similarity values obtained for strain HR3$23^{\mathrm{T}}$ and its closest phylogenetic neighbours were low enough to exclude high DNA-DNA reassociation values that would indicate membership to one of these species (Stackebrandt \& Goebel, 1994).

\section{Description of Bacillus silvestris sp. nov.}

Bacillus silvestris (sil.ves'tris. N.L. masc. n. silva forest, referring to the place of isolation).

Gram-positive, rod-shaped, peritrichously flagellated, endospore-forming, strictly aerobic organism. Round spores lie terminally in a swollen sporangium. The rods measure $0.9-2.0 \mu \mathrm{m}$ by $0.5-0.7 \mu \mathrm{m}$; spore diameters are $0.5-0.7 \mu \mathrm{m}$. The peptidoglycan contains lysine, glutamic acid and alanine, representing peptidoglycan type A $4 \alpha$. Polar lipids comprise phosphatidylglycerol, diphosphatidylglycerol, phosphatidylethanolamine, minor amounts of phosphatidylserine and one unknown phospholipid. The dominant isoprenoid quinone is of the MK-7 type. The fatty acid profile is characterized by the predominance of iso- $\mathrm{C}_{15: 0}$ $(44.2 \%)$, followed by iso- $\mathrm{C}_{16: 1}(18.7 \%)$ fatty acids. Further compounds are: iso- $\mathrm{C}_{17: 1}(7.8 \%)$, iso- $\mathrm{C}_{16: 0}$ $(6 \cdot 2 \%)$, anteiso- $\mathrm{C}_{15: 0}(5 \cdot 6 \%)$, iso- $\mathrm{C}_{17: 0}(5 \cdot 1 \%), \mathrm{C}_{16: 1}$ $(3.1 \%)$, anteiso-C $\mathrm{C}_{17: 0}(3.0 \%)$, iso- $\mathrm{C}_{14: 0}(2.9 \%)$, anteiso- $\mathrm{C}_{17: 1}(2 \cdot 8 \%)$ and $\mathrm{C}_{17: 0}(0 \cdot 9 \%)$. Temperature range for growth is $10-40^{\circ} \mathrm{C}$ with an optimum between 20 and $30^{\circ} \mathrm{C}$. Catalase-positive, oxidase-negative, VP test-negative, no pH change in the growth medium. Reactions towards the substrates provided in the API $50 \mathrm{CH}$ panel indicate that glycerol and ribose are utilized as sole carbon sources, but acid is not produced. No acid from and no utilization of $\mathrm{D}$ glucose, erythritol, D- and L-arabinose, D- and Lxylose, adonitol, methyl $\beta$,D-xyloside, galactose, mannose, D-mannitol, D-fructose, L-sorbose, rhamnose, dulcitol, inositol, sorbitol, methyl $\alpha$,D-mannoside, methyl $\alpha$,D-glucoside, $N$-acetylglucosamine, amygdalin, arbutin, aesculin, salicin, cellobiose, maltose, lactose, melibiose, sucrose, trehalose, inulin, melezitose, D-raffinose, starch, glycogen, xylitol, $\beta$ gentiobiose, $\mathrm{D}$-turanose, $\mathrm{D}$-lyxose, $\mathrm{D}$-tagatose, $\mathrm{D}-$ and L-fucose, D- and L-arabitol, gluconate, 2-ketogluconate and 5-ketogluconate. Casein, gelatin, starch, Tween 80 and aesculin are not hydrolysed. Citrate or propionate are not utilized and tyrosine is not degraded. Deamination of phenylalanine and the egg yolk lecithinase test are negative. Nitrite is not produced from nitrate, indole is not formed. The strain does not grow at $\mathrm{pH} 5.7$ or in the presence of lysozyme. It grows in the presence of 0,2 and $5 \%(\mathrm{w} / \mathrm{v}) \mathrm{NaCl}$ in modified Difco tryptic soy broth agar. Arginine dihydrolase is not present. The $\mathrm{G}+\mathrm{C}$ content of the DNA is $39 \cdot 3$ mol $\%$, as determined by HPLC. Phylogenetically, a member of the Bacillus RNA group 2. Isolated from the top soil layer of a beech forest soil near Braunschweig, Lower Saxony, Germany. The type strain is HR3-23 ${ }^{\mathrm{T}}\left(=\mathrm{DSM} 12223^{\mathrm{T}}\right)$.

\section{ACKNOWLEDGEMENTS}

We wish to thank Ina Kramer, Ellruth Müller and Jutta Burghardt for their assistance. Dagmar Fritze and Maike Steffen are thanked for many helpful discussions. H. R. was supported by a grant from the German Research Council to E.S. (DFG-Sta 184/13-1).

\section{REFERENCES}

Ash, C., Farrow, J. A. E., Wallbanks, S. \& Collins, M. D. (1991). Phylogenetic heterogeneity of the genus Bacillus as revealed by comparative analysis of small-subunit-ribosomal RNA sequences. Lett Appl Microbiol 13, 202-206.

Ash, C., Priest, F. G. \& Collins, M. D. (1993). Molecular identification of rRNA group 3 bacilli (Ash, Farrow and Collins) using a PCR probe test. Antonie Leeuwenhoek 64, 253-260.

Brosius, J., Palmer, M. L., Kennedy, P. J. \& Noller, H. F. (1978). Complete nucleotide sequence of the 16S ribosomal RNA gene from Escherichia coli. Proc Natl Acad Sci USA 75, 4801-4805.

Claus, D. \& Berkeley, R. C. W. (1986). Genus Bacillus Cohn 1872 In Bergey's Manual of Systematic Bacteriology, vol. 2, pp. 1105-1140. Edited by P. H. A. Sneath, N. S. Mair, M. E. Sharpe \& J. G. Holt. Baltimore: Williams \& Wilkins.

Claus, D. \& Fahmy, F. (1986). Genus Sporosarcina Kluyver and van Niel 1936, 401 ${ }^{\mathrm{AL}}$. In Bergey's Manual of Systematic Bacteriology, vol. 2, pp. 1202-1206. Edited by P. H. A. Sneath, N. S. Mair, M. E. Sharpe \& J. G. Holt. Baltimore: Williams \& Wilkins.

Claus, D. \& Fritze, D. (1989). Taxonomy of Bacillus. In Bacillus, Biotechnology Handbooks 2, pp. 5-26. Edited by C. R. Harwood. New York: Plenum.

Clausen, V., Jones, J. G. \& Stackebrandt, E. (1985). 16S ribosomal RNA analysis of Filibacter limicola indicates a close relationship to the genus Bacillus. J Gen Microbiol 131, 2659-2663.

Collins, M. D. \& Jones, D. (1979). Isoprenoid quinone composition as a guide to the classification of Sporolactobacillus and possibly related bacteria. J Appl Bacteriol 47, 293-297.

Collins, M. D. \& Jones, D. (1980). Lipids in the classification and identification of coryneform bacteria containing peptidoglycans based on 2,4-diaminobutyric acid. $J$ Appl Bacteriol 48, 459-470.

Collins, M. D., Pirouz, T., Goodfellow, M. \& Minnikin, D. E. (1977). Distribution of menaquinones in actinomycetes and corynebacteria. J Gen Microbiol 100, 221-230.

De Soete, G. (1983). A least squares algorithm for fitting additive trees to proximity data. Psychometrika 48, 621-626.

Fahmy, F., Flossdorf, J. \& Claus, D. (1985). The DNA base composition of the type strains of the genus Bacillus. Syst Appl Microbiol 6, 60-65. 
Farrow, J. A. E., Ash, C., Wallbanks, S. \& Collins, M. D. (1992). Phylogenetic analysis of the genera Planococcus, Marinococcus and Sporosarcina and their relationships to members of the genus Bacillus. FEMS Microbiol Lett 93, 167-172.

Farrow, J. A. E., Wallbanks, S. \& Collins, M. D. (1994). Phylogenetic interrelationships of round-spore-forming bacilli containing cell walls based on lysine and the non-spore-forming genera Caryophanon, Exiguobacterium, Kurthia, and Planococcus. Int $J$ Syst Bacteriol 44, 74-82.

Felsenstein, J. (1985). Confidence limits on phylogenies: an approach using the bootstrap. Evolution 39, 783-789.

Felsenstein, J. (1993). PHYLIP: Phylogeny inference package, version 3.5.1. Department of Genetics, University of Washington, Seattle, WA, USA.

Gordon, R. E., Haynes, W. C. \& Pang, C. H. (1973). The genus Bacillus. Agricultural Handbook 427. Washington, DC: USDA.

Groth, I., Schumann, P., Weiss, N., Martin, K. \& Rainey, F. A. (1996). Agrococcus jenensis gen. nov., sp. nov., a new genus of actinomycetes with diaminobutyric acid in the cell wall. Int $J$ Syst Bacteriol 46, 234-239.

Hao, M. V., Kocur, M. \& Komagata, K. (1985). A new species of Planococcus, $P$. kocurii, isolated from fish, frozen foods and fish curing brine. $J$ Gen Microbiol 31, 441-455.

Heimbrook, M. E., Wang, W. L. L. \& Campbell, G. (1989). Staining bacterial flagella easily. $J$ Clin Microbiol 27, 2612-2615.

Hess, A., Hollander, R. \& Mannheim, W. (1979). Lipoquinones of some spore-forming rods, lactic acid bacteria and actinomycetes. J Gen Microbiol 115, 247-252.

Heyndrickx, M., Lebbe, L., Kersters, K., De Vos, P., Forsyth, G. \& Logan, N. A. (1998). Virgibacillus: a new genus to accommodate Bacillus pantothenticus (Proom and Knight 1950). Emended description of Virgibacillus pantothenticus. Int J Syst Bacteriol 48, 99-106.

Holt, J. G., Krieg, N. R., Sneath, P. H. A., Staley, J. T. \& Williams, S. T. (1994). Group 19, regular, nonsporing Gram-positive rods. In Bergey's Manual of Determinative Bacteriology, 9th edn, pp. 565-570. Baltimore: Williams \& Wilkins.

Jukes, T. H. \& Cantor, C. R. (1969). Evolution of protein molecules, In Mammalian Protein Metabolism, pp. 21-132. Edited by H. N. Munro. New York: Academic Press.

Kocur, M. (1986). Genus Planococcus. In Bergey's Manual of Systematic Bacteriology, vol. 2, pp. 1011-1013. Edited by P. H. A. Sneath, N. S. Mair, M. E. Sharpe \& J. G. Holt. Baltimore: Williams \& Wilkins.

Lanyi, B. (1989). Characterization tests appropriate for numerical taxonomic studies. Methods Microbiol 19, 1-67.

MacKenzie, S. L. (1987). Gas chromatographic analysis of amino acids as the $N$-heptafluorobutyryl isobutyl esters. $J$ Assoc Off Anal Chem 70, 151-160.

Maidak, B. L., Olsen, G. J., Larsen, N., Overbeek, R., McCaughey, M. J. \& Woese, C. R. (1997). The RDP (Ribosomal Database Project). Nucleic Acids Res 25, 109-111.

Maiden, M. F. J. \& Jones, J. G. (1984). A new filamentous, gliding bacterium, Filibacter limicola gen. nov., sp. nov., from lake sediment. J Gen Microbiol 130, 2943-2959.

Mesbah, M., Premachandran, U. \& Whitman, W. B. (1989). Precise measurement of the $\mathrm{G}+\mathrm{C}$ content of deoxyribonucleic acid by high-performance liquid chromatography. Int $J$ Syst Bacteriol 39, 159-167.

Minnikin, D. E., Alshamaony, L. \& Goodfellow, M. (1975).
Differentiation of Mycobacterium, Nocardia, and related taxa by thin-layer chromatographic analysis of whole-organism methanolysates. J Gen Microbiol 88, 200-204.

Minnikin, D. E., Collins, M. D. \& Goodfellow, M. (1979). Fatty acid and polar lipid composition in the classification of Cellulomonas, Oerskovia and related taxa. J Appl Bacteriol 47, 87-95.

Pechman, K. J., Lewis, B. J. \& Woese, C. R. (1976). Phylogenetic status of Sporosarcina ureae. Int J Syst Bacteriol 26, 305-310.

Priest, F. G., Goodfellow, M. \& Todd, C. (1988). A numerical classification of the genus Bacillus. J Gen Microbiol 134, 1847-1882.

Rainey, F. A. \& Stackebrandt, E. (1993). Phylogenetic evidence for the relationship of Saccharococcus thermophilus to Bacillus thermoglucosidasius, Bacillus kaustophilus and Bacillus stearothermophilus. Syst Appl Microbiol 16, 224-226.

Rainey, F. A., Fritze, D. \& Stackebrandt, E. (1994). The phylogenetic diversity of thermophilic members of the genus Bacillus, as revealed by $16 \mathrm{~S}$ rDNA analysis. FEMS Microbiol Lett 115 , 205-212.

Rainey, F. A., Ward-Rainey, N., Kroppenstedt, R. M. \& Stackebrandt, E. (1996). The genus Nocardiopsis represents a phylogenetically coherent taxon and a distinct actinomycete lineage: proposal of Nocardiopsaceae fam. nov. Int $J$ Syst Bacteriol 46, 1088-1092.

Ranftl, H. \& Kandler, O. (1970). D-aspartyl-L-alanin als Interpeptidbrücke im Murein von Bacillus pasteurii Migula. $Z$ Naturforsch 28C, 4-8.

Sambrook, J., Fritsch, E. F. \& Maniatis, T. (1989). Molecular Cloning: a Laboratory Manual, 2nd edn. Cold Spring Harbor, NY: Cold Spring Harbor Laboratory.

Schleifer, K. H. \& Kandler, O. (1972). Peptidoglycan types of bacterial cell walls and their taxonomic implications. Bacteriol Rev 36, 407-477.

Shaw, S. \& Keddie, R. M. (1983). A numerical taxonomic study of the genus Kurthia with a revised description of Kurthia zopfii and a description of Kurthia gibsonii sp. nov. Syst Appl Microbiol 4, 253-276.

Shida, O., Takagi, H., Kadowaki, K. \& Komagata, K. (1996). Proposal for two new genera, Brevibacillus gen. nov. and Aneurinibacillus gen. nov. Int J Syst Bacteriol 46, 939-946.

Sneath, P. H. A. (1986). Section 13. Endospore-forming Grampositive rods and cocci. In Bergey's Manual of Systematic Bacteriology, vol. 2, pp. 1104-1105. Edited by P. H. A. Sneath, N. S. Mair, M. E. Sharpe \& J. G. Holt. Baltimore: Williams \& Wilkins.

Spurr, A. R. (1969). A low viscosity epoxy resin embedding medium for electron microscopy. J Ultrastruct Res 26, 31-43.

Stackebrandt, E. \& Goebel, B. (1994). Taxonomic note: a place for DNA-DNA reassociation and $16 \mathrm{~S}$ rRNA sequence analysis in the present species definition in bacteriology. Int $J$ Syst Bacteriol 44, 846-849.

Stackebrandt, E., Ludwig, W., Weizenegger, M., Dorn, S., McGill, T. J., Fox, G. E., Woese, C. E., Schubert, W. \& Schleifer, K.-H. (1987). Comparative 16S rRNA oligonucleotide analyses and murein types of round-spore-forming bacilli and non-sporeforming relatives. $J$ Gen Microbiol 133, 2523-2529.

Stead, D. E., Sellwood, J. E., Wilson, J. \& Viney, I. (1992). Evaluation of a commercial identification system based on fatty acid profiles for rapid, accurate identification of plant pathogenic bacteria. J Appl Bacteriol 72, 315-321.

Trentini, W. C. (1986). Genus Caryophanon Peshkoff 1939, 244 ${ }^{\mathrm{AL}}$. 
In Bergey's Manual of Systematic Bacteriology, vol. 2, pp. 1259-1260. Edited by P. H. A. Sneath, N. S. Mair, M. E. Sharpe \& J. G. Holt. Baltimore: Williams \& Wilkins.

Wisotzkey, J. D., Jurtshuk, P., Jr, Fox, G. E., Deinhard, G. \& Poralla, K. (1992). Comparative sequence analysis on the $16 \mathrm{~S}$ rRNA of Bacillus acidocaldarius, Bacillus acidoterrestris and
Bacillus cycloheptanicus: proposal for a new genus Alicyclobacillus gen. nov. Int J Syst Bacteriol 42, 263-269.

Yamada, K. \& Komagata, K. (1972). Taxonomic studies on coryneform bacteria. IV. Morphological, cultural, biochemical, and physiological characteristics. J Gen Appl Microbiol 18, 399-416. 